\title{
Communication
}

[Comunicação]

\section{Multidrug-resistant Shiga toxin-producing Escherichia coli in dogs with diarrhea}

\author{
[Escherichia coli Shiga toxigênica resistente a múltiplas drogas isoladas de cães com diarreia] \\ C.J.S. Paula ${ }^{1}$ J.M. Marin ${ }^{2 *}$ \\ ${ }^{1}$ Aluno de pós-graduação - FCAV-UNESP - Jaboticabal, SP \\ ${ }^{2}$ Departamento de Morfologia, Estomatologia e Fisiologia - FORP-USP \\ Avenida do Café $\mathrm{s} / \mathrm{n}$ \\ 14040-904 - Ribeirão Preto, SP
}

Increased prevalence of antimicrobials resistance of pathogenic bacteria is a growing world wide concern. Its major risk factor has been generally considered as a consequence of the wide use of antimicrobials leading to the emergence and dissemination of resistant bacteria and resistance genes (van den Bogaard and Stobberingh, 2000). Pet animals, especially dogs, represent potential sources for the spreading of antimicrobial resistance resulting from the extensive use of antimicrobial agents in these animals and their close contact with humans (Guardabassi et al., 2004). Reports of extra-intestinal infections in dogs due to multidrug-resistant Escherichia coli (MDREC) strains, resistant to third-generation cephalosporins and fluoroquinolones, have aroused special concern (Warren et al., 2001; Sanchez et al., 2002). Canine MDREC have been shown to harbor class 1 integron-associated resistance genes that had been identified in bacteria isolated from human clinical infections suggesting the spread of resistance mechanisms from canine to human bacteria, possibly via coselection and transfer of multidrug resistance plasmids (Kang et al., 2005). Although the transfer of integrons between human and animal bacterial strains has not been fully explained, it is known that resistance to antimicrobial agent can spread from animals to humans via transferable plasmids (Winokur et al., 2001).

An emerging pathogen, Shiga toxin-producing $E$. coli (STEC) of the O157:H7 serotype, has been considered to be responsible for many outbreaks of hemorrhagic colitis and the hemolytic uremia syndrome in humans (Caprioli et al., 2005). However, other E. coli serogroups, known to be non-O157, are also important and prevalent in animals, suggesting that humans may also be exposed to them (Blanco et al., 2004). Two types of Shiga toxins, known as stx 1 and stx 2, constitute the main virulence factor in STEC strains (Law, 2000), commonly isolated from the feces of ruminants, like cattle and sheep (Kudva et al., 1997; Rigobelo et al., 2006), and occasionally from pigs (Macedo et al., 2007). Dogs have also been found to carry STEC strains, but their role as bacterial reservoirs has not been totally elucidated (Bentancor et al., 2007). The prevalence of STEC strains among intestinal bacterial strains has been shown to be of highly variable occurrence (Bentancor et al., 2007).

The use of antimicrobial drugs for diarrhea treatment remains questionable, in special when STEC strains are involved; nevertheless, intensive use of antimicrobial drugs in pets has been well documented (Guardabassi et al., 2004). Dogs that carry MDREC in their feces may readily contaminate the environment and are potential sources for the transmission of these bacteria to other animals and to humans (Warren et al., 2001). Thus, it was the aim of the present work, to study the occurrence of STEC strains in diarrheic dogs, and to examine their susceptibility to 11 antimicrobial agents, to verify their multidrug resistance patterns, and to assess their significance as sources of infection.

Recebido em 28 de maio de 2008

Aceito em 4 de fevereiro de 2009

* Autor para correspondência (corresponding author)

E.mail: jmmarin@forp.usp.br 
From January to December of 2006, 25 diarrheic dogs were examined after their arrival for consultation at a private clinic in the city of Ituverava, SP, Brazil. Samples collected by rectal swabbing, under the supervision of a veterinarian, were placed in a Stuart transport medium and taken to a laboratory for immediate processing. They were transferred to MacConkey agar $^{1}$, and incubated for $24 \mathrm{~h}$ at $37^{\circ} \mathrm{C}$. At least five randomly chosen colonies from each plate were selected for analysis. Biochemical confirmation of the strains as $E$. coli was performed according to Koneman et al. (1997). Bacteria overnight grown in nutrient broth ${ }^{2}$ at $37^{\circ} \mathrm{C}$ were tested for the presence of stx genes (stx 1 and stx 2), using the polymerase chain reaction (PCR) protocol of Orden et al. (1998). DNA templates were prepared from bacterial cells, resuspended in sterile distilled water, and boiled at $100^{\circ} \mathrm{C}$ for $10 \mathrm{~min}$. Reference $E$. coli strains used as controls were EDL 933 (O157:H7, stx 1, stx 2, and eae); DH5 $\alpha$ was used as the negative control. STEC samples were typed for the serotype O157 using the O157 latex agglutination test $\mathrm{kit}^{3}$. Negative strains on agglutination were considered non-O157 strains.

Antimicrobial disk susceptibility tests were performed using the disk diffusion method, recommended by the NCCLS (Performance...,
2002). Drug-impregnated disks ${ }^{4}$ were placed on the surface of the agar using a disk dispenser.

The following 11 antimicrobial agents were tested for bacterial resistance: ampicillin, amoxicillin, amoxicillin/clavulanic acid, amikacin, cephalothin, gentamicin, tetracycline, streptomycin, nalidixic acid, cotrimoxazole, and ciprofloxacin.

A total of $92 \mathrm{E}$. coli strains were isolated from the 25 diarrheic dogs, and all of them were investigated by PCR for the presence of Shiga toxin-producing genes (stx 1 and stx 2). Table 1 shows that $12(13.0 \%)$ of the strains carried the stx gene; seven $(7.6 \%)$ carried only the stx 1 gene, five $(5.4 \%)$ the stx 2 gene, and none carried both genes. All STEC isolated strains were tested by the $\mathrm{O} 157$ latex agglutination test kit; no $\mathrm{O} 157$ was detected in the isolated strains. The occurrence of stx genes (40.0\%) among $E$. coli samples from diarrheic animals in the present study agrees with the results on the same subject reported by Hammermuler et al. (1995), i.e $44.4 \%$, as well as the presence of stx 1 or stx 2 genes among STEC strains, but not of both of them together. However, it is noteworthy that Nakazato et al. (2004), in Brazil, did not find STEC strains carrying stx 1 or stx 2 genes among 146 diarrheic and 36 healthy dogs examined.

Table 1. Distribution of Shiga toxin genes and resistance pattern of strain of Shiga- toxin-producing Escherichia coli from twenty-five diarrheic dogs in Ituverava, São Paulo

\begin{tabular}{ccl}
\hline Strain* & Genetic marker & \multicolumn{1}{c}{ Resistance pattern } \\
\hline 10.3 & stx 1 & AMP, AMO, AMC, CFL, GEN, STR, AMK, NAL, SUT \\
20.2 & stx 1 & AMP, AMO, CFL, GEN, STR, SUT \\
36.4 & stx 2 & AMP, AMO, CFL, TET, GEN, STR, SUT \\
37.2 & stx 1 & CFL, TET, STR \\
39.4 & stx 1 & AMP, CFL, TET, GEN, STR \\
44.3 & stx 2 & AMP, AMO \\
46.1 & stx 2 & CFL, TET, GEN, STR, AMK \\
47.3 & stx 2 & AMP, AMO, CFL, TET, GEN, STR, NAL, CIP \\
47.4 & stx 1 & AMO \\
48.3 & stx 2 & AMP, CFL, GEN, STR, AMK, NAL, CIP \\
& \\
& \\
${ }^{1}$ Mac-Difco- Difco - USA. \\
${ }^{2}$ Sigma Chemical Co - St Louis, USA. \\
3Oxoid, Basingstoke - Hampshire, UK. \\
${ }^{4}$ CEFAR - São Paulo, Brazil.
\end{tabular}


51.3 stx $1 \quad$ CFL, NAL

51.4 stx $1 \quad$ STR

*Number of the strains. AMP: ampicillin; AMO: amoxicillin; AMC: amoxicillin/clavulanic acid; CFL: cephalothin; GEN: gentamicin; STR: streptomycin; AMK: amikacin; NAL: nalidixic acid; SUT: cotrimoxazole; TET: tetracycline; CIP: ciprofloxacin.

The existence of multidrug-resistant phenotypes among bacteria housed by animals has been a cause of concern to veterinarians. Sanchez et al. (2002) reported the isolation of E. coli resistant to 12 antimicrobial drugs from two dogs; and Warren et al. (2001), the isolation of 18 multidrug-resistant E. coli strains from 10 dogs in Australia; all showed an extended spectrum of $\beta$ lactamase activity. Normand et al. (2000) reported that $30 \%$ of the E. coli samples isolated from dogs that they examined in England were multidrug-resistant; however, all of them did not work with STEC strains.

In the present work, among the 12 STEC isolated samples examined, seven (58\%) presented a MDREC phenotype resistant to four or more antimicrobial drugs, although it is not common for STEC strains to exhibit resistance to several antimicrobial drugs (Bettelheim et al., 2003). However, Cergole-Novella et al. (2006) also reported the isolation of STEC strains from humans and from bovine species in Brazil showing resistance to five or six antimicrobial drugs.

The carrying of MDREC organisms by dogs represents a potential hazard for people having contact with such animals, running the risk of spreading resistance genes. In the present study, results showing a high percentage of STEC strains isolated from diarrheic dogs, presenting a multidrug-resistance phenotype, give rise to considerable concern and suggest that monitoring of the extent of this problem is an advisable measure.

Keywords: Escherichia coli, diarrheic dogs, STEC, multidrug-resistance

\section{ACKNOWLEDGMENTS}

The authors thank FAPESP for financial support.

\section{RESUMO}

Noventa e duas amostras de Escherichia coli, isoladas de 25 cães diarreicos, em Ituverava, SP, foram examinadas para a detecção dos genes codificadores de Shiga toxinas ( $\mathrm{stx} 1$ e stx 2). Por meio da reação em cadeia da polimerase, foram identificadas sete amostras positivas para o gene stx 1 e cinco para o gene stx 2, não foi detectada nenhuma amostra com os dois genes. As 12 amostras que apresentavam genes codificadores de Shiga toxinas (stx 1 e stx), foram testadas frente a 11 agentes antimicrobianos, sendo que sete delas (58,0\%) apresentaram resistência a múltiplas drogas, o que representa um motivo de preocupação.

Palavras-chave: Escherichia coli, cão diarreico, STEC, resistência a múltiplas drogas

\section{REFERENCES}

BENTANCOR, A.; RUMI, M.V.; GENTILINI, M.V. et al. Shiga toxin-producing and attaching and effacing Escherichia coli in cats and dogs in a high hemolytic uremic syndrome incidence region in Argentina. FEMS Microbiol. Lett., v.267, p.251-256, 2007.

BETTELHEIM, K.A.; HORNITZKY, M.A.; DJORDJEVIC, S.P et al. Antibiotic resistance among verocytotoxigenic Escherichia coli (VTEC) and non-VTEC isolated from domestic animals and humans. J. Med. Microbiol., v.52, p.155-162, 2003.

BLANCO, M.; BLANCO, J.E.; MORA. et al. Serotypes, virulence genes, and intimin types of Shiga toxin (verotoxin)-producing Escherichia coli isolates from cattle in Spain and identification of a new intimin variant gene (eae ع). J. Clin. Microbiol.,v.42, p.645-651, 2004.

CAPRIOLI, A.; MORABITO, S.; BRUGERE, H. et al. Enterohaemorrhagic Escherichia coli 
emerging issues on virulence and modes of transmission. Vet. Res., v.36, p.289-311, 2005.

CERGOLE-NOVELLA, M.C.; NISHIMURA, L.S.; IRINO, K. et al. Stx genotypes and antimicrobial resistance profiles of Shiga toxinproducing Escherichia coli strains isolated from human infections, cattle and foods in Brazil. FEMS Microbiol. Lett., v.259, p.234-239, 2006.

GUARDABASSI, L.; SCHWARZ, S.; LOYD1, D.H. Pet animals as reservoirs of antimicrobialresistant bacteria. J. Antimicrob. Chemother., v.54, p.321-332, 2004.

HAMMERMUELLER, J.; KRUTH, S.; PRESCOT, J. et al. Detection of toxin genes in Escherichia coli isolated from normal dogs and dogs with diarrhea. Can. J. Vet. Res., v.59, p.265-270, 1995.

KANG, H.Y.; JEONG, Y.S.; OH, J.Y. et al. Characterization of antimicrobial resistance and class 1 integrons found in Escherichia coli isolates from humans and animals in Korea. $J$. Antimicrob. Chemother., v.55, p.639-644, 2005.

KONEMAN, E.W.; ALLEN, S.D.; SCHREKENBERGER, P. et al. Color atlas and textbook of diagnostic microbiology. 5.ed. Philadelphia: J.B. Lippincott, 1997. 1488p.

KUDVA, I. T.; HETFIELD, P.G.; HOVDE, C.J. Characterization of Escherichia coli O157: H7 and other Shiga toxin-producing $E$. coli serotypes isolated from sheep. J. Clin. Microbiol., v.35, p.892-899, 1997.

LAW, D. Virulence factors of Escherichia coli O 157 and other Shiga toxin-producing E. coli. J. Appl. Microbiol., v.88, p.729-745, 2000.

MACEDO, N.R.; MENEZES, C.P.L.; LAGE, A.P. Detecção de cepas patogênicas pela PCR multiplex e avaliação da sensibilidade a antimicrobianos de Escherichia coli isolada de leitões diarreicos. Arq. Bras. Med. Vet. Zootec., v.59, p.1117-1123, 2007.

NAKAZATO, G.; GYLES, C.; ZIEBELL, K. et al. Attaching and effacing Escherichia coli isolated from dogs in Brazil: characteristics and serotypic relationship to human enteropathogenic E. coli (EPEC). Vet. Microbiol., v.101, p.269$277,2004$.

NORMAND, E.H.; GIBSON, N.R.; TAYLOR, D.J. et al. Trends of antimicrobial resistance in bacterial isolates from a small animal referral hospital. Vet. Rec., v.146, p.151-155, 2000.

ORDEN, J.A.; RUIZ-SANTA-QUITERIA, J.A.; CID, D. et al. Verotoxin-producing Escherichia coli (VTEC) and eae-positive non-VTEC in 1-30 days-old diarrhoeic dairy calves. Vet. Microbiol., v.63, p.239-248, 1998.

PERFORMANCE standards for antimicrobial disk and dilution susceptibility test for bacteria isolated from animals approved Standard M31A2. Wayne, PA: National Committee For Clinical Laboratory, 2002.

RIGOBELO, E.C.; GAMEZ, H.J.; MARIN, J.M. et al. Virulence factors of Escherichia coli isolated from diarrheic calves. Arq. Bras. Med. Vet. Zootec., v.58, p.305-310, 2006.

SANCHEZ, S.; McCRACKIN STEVENSON, M.A.; HUDSON, C.R. et al Characterization of multidrug-resistant Escherichia coli isolates associated with nosocomial infection in dogs. $J$. Clin. Microbiol., v.40, p.3586-3595, 2002.

VAN DEN BOGAARD, A.E.; STOBBERINGH, E.E. Epidemiology of resistance to antibiotics. Links between animals and humans. Int. J. Antimicrob. Agents, v.14, p.327-335, 2000.

WARREN, A.I.; TOWNSEND, K.M.; KING, T. et al. Multi-drug resistant Escherichia coli with extended-spectrum $\beta$-lactamase activity and fluoroquinolone resistance isolated from clinical infections in dogs. Aust. Vet. J., v.79, p.621-623, 2001.

WINOKUR, P.L.; VONSTEIN, D.L.; HOFFMAN, J.J et al. Evidence for transfer of CMY-2 AmpC $\beta$-lactamase plasmids between Escherichia coli and Salmonella isolates from food animals and humans. Antimicrob. Agents Chemother., v.45, p.2716-2722, 2001. 